\title{
Ionic Conductivity of Network Polymers from Poly(ethylene oxide) Containing Lithium Perchlorate
}

\author{
Masayoshi Watanabe, Satoshi Nagano, Kohei SANui, \\ and Naoya OGATA \\ Department of Chemistry, Sophia University, 7-1 Kioi-cho, \\ Chiyoda-ku, Tokyo 102, Japan \\ (Received April 8, 1986)
}

\begin{abstract}
The structure-conductivity relationships were investigated on the network polymers from poly(ethylene oxide) (PEO) containing lithium perchlorate $\left(\mathrm{LiClO}_{4}\right)$, in contrast to the polymer complex formed by linear PEO and $\mathrm{LiClO}_{4}$. The crosslinked structure caused a considerable decrease in the degree of the crystallinity of the resulting PEO- $\mathrm{LiClO}_{4}$ complexes, which contributed to high ionic conductivity. $\mathrm{Li}^{+}$ions were demonstrated as mobile species in these polymer complexes, while $\mathrm{ClO}_{4}^{-}$ions contributed somewhat to ionic conductivity. The high ionic conductivity of the order of $10^{-5} \mathrm{~S} \mathrm{~cm}^{-1}$ at $30^{\circ} \mathrm{C}$ was attained by a crosslinked $\mathrm{PEO}-\mathrm{LiClO}_{4}$ complex of $\left[\mathrm{LiClO}_{4}\right] /[\mathrm{EO}$ unit $]=0.02$.

KEY WORDS Ionic Conductor / Polymer Electrolytes / Poly(ethylene oxide) / Network Polymer / Crystallinity /
\end{abstract}

Poly(ethylene oxide) (PEO) is known to form crystalline complexes with inorganic and organic substances, such as $\mathrm{HgCl}_{2}{ }^{1}$ and urea. ${ }^{2}$ Wright et al. ${ }^{3}$ first reported that PEO formed crystalline complexes with alkali metal salts, which had considerably higher melting points $\left(\sim 180^{\circ} \mathrm{C}\right)$ than that of pure PEO $\left(\sim 60^{\circ} \mathrm{C}\right)$. The complexation was considered to involve coordination of the ether oxygen atoms to the cation, as seen in macrocyclic polyether complexes. As a result, the PEO complexes were considered to have helical structures, in which the cations were arranged. They also reported relatively high electrical conductivity of the PEO complexes. ${ }^{3}$ Armand et al. $^{4}$ demonstrated ionic character of the electrical conductivity, which reached $10^{-5}$ $\mathrm{S} \mathrm{cm}^{-1}$ at moderate temperatures $\left(50-70^{\circ} \mathrm{C}\right)$, and pointed out potential application of the PEO complexes to solid electrolytes in high energy density batteries. Since then, a number of studies ${ }^{5-12}$ have been carried out on the electrical property, X-ray structure, thermal property, and vibrational spectroscopy of the PEO complexes.

The PEO complexes have, in general, multiphase nature, consisting of the salt-rich crystalline phase, pure PEO crystalline phase, and amorphous phase with dissolved salt. It has been revealed that the ionic conduction takes place primarily in the amorphous phase. ${ }^{11}$ The phase diagram is affected by many factors, such as the salt species and concentration, temperature, thermal history, and preparation method. Thus, the temperature dependence of ionic conductivity shows complicated profiles, depending on the change in the phase diagram with temperature. ${ }^{11}$ At the present, amorphous PEO complexes are considered to be suitable for achieving high and stable conductivity. The use of network polymers is an interesting way to obtain amorphous PEO complexes without losing mechanical strength, and several attempts have been carried out. $8,9,12$

We have studied ${ }^{13-20}$ structure-conductivity 
relationships in certain kinds of ion-containing polymers. The polymers, such as poly(propylene oxide $),{ }^{13-16} \operatorname{poly}(\beta$-propiolactone $),{ }^{17}$ poly(ethylene succinate) ${ }^{18,19}$ and poly(ethylene oxide-co-dimethylsiloxane) ${ }^{20}$ have been selected as host polymers to alkali metal salts. In this study we selected a combination of $\mathrm{LiClO}_{4}$ and network polymers of PEO in order to achieve high ionic conductivity in the PEO system. $\mathrm{LiClO}_{4}$ was used because this salt did not form crystalline complexes with PEO in the low concentration region investigated in this study. ${ }^{21}$ The effects of the network structure on the degree of crystallinity of the complexes and on ionic conductivity were investigated in contrast to the polymer complex formed by linear PEO and $\mathrm{LiClO}_{4}$

\section{EXPERIMENTAL}

\section{Material}

Triol-type PEO, supplied by Dai-ichi Kogyo Seiyaku Co., was dissolved in distilled benzene, $\cdot$ precipitated from $n$-hexane, and dried under reduced pressure $\left(10^{-3}\right.$ torr $)$ at $80^{\circ} \mathrm{C}$ for $8 \mathrm{~h}$. The molecular characteristics of the trioltype PEO are shown in Table I. Linear PEO (Aldrich, average mol wt $=10^{5}$ ) was purified by the precipitation method. A special grade anhydrous $\mathrm{LiClO}_{4}$ (Mitsuwa Kagaku Co.) was dried under reduced pressure $\left(10^{-3}\right.$ torr $)$ at $180^{\circ} \mathrm{C}$ for $8 \mathrm{~h}$.

The network polymers were synthesized by a crosslinking reaction of the triol-type PEO with 4-methyl-1,3-phenylene diisocyanate, as shown in Figure 1. With respect to functional groups, stoichiometric amounts of PEO and freshly distilled diisocyanate were mixed sufficiently at $75^{\circ} \mathrm{C}$ and cast on glass substrates. The crosslinking reaction occurred at $75^{\circ} \mathrm{C}$ under dry nitrogen atmosphere for $72 \mathrm{~h}$ and in vacuo for $24 \mathrm{~h}$. Unreacted precursors were removed from the network films by extraction with distilled acetone by several times. The resulting network films with thickness of about $0.4 \mathrm{~mm}$ were dried sufficiently in vacuo

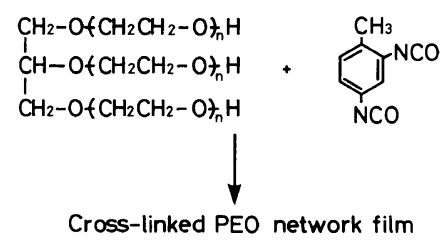

Figure 1. Preparation of crosslinked PEO network polymers.

Table I. Molecular characteristics of triol-type PEO and crosslinked PEO

\begin{tabular}{|c|c|c|c|}
\hline \multicolumn{2}{|c|}{ Triol-type PEO } & \multicolumn{2}{|c|}{ Crosslinked PEO } \\
\hline $\begin{array}{l}\text { Number average } \\
\text { molecular weight }\end{array}$ & $n^{\mathrm{b}}$ & $\begin{array}{l}\text { Weight fraction } \\
\text { of PEO }\end{array}$ & $Q_{\mathrm{w}}{ }^{\mathrm{c}}$ \\
\hline 3000 & 22 & 0.91 & 3.0 \\
\hline \multicolumn{4}{|c|}{$\begin{array}{l}\text { a Determined by } \mathrm{OH} \text { titration. } \\
\text { b Average number of } n \text { in Figure } 1 . \\
\text { c Weight swelling ratio toward water at } 27^{\circ} \mathrm{C} \text {. }\end{array}$} \\
\hline
\end{tabular}

at $80^{\circ} \mathrm{C}$ for $72 \mathrm{~h}$. The weight swelling ratio toward water $\left(Q_{w}\right)$ at $27^{\circ} \mathrm{C}$ is shown in Table $\mathrm{I}$.

An immersion method was used for dissolution of $\mathrm{LiClO}_{4}$ in the network films, since the films were swollen by an acetone solution of $\mathrm{LiClO}_{4}$. A pre-weighed film was immersed in an acetone solution of $\mathrm{LiClO}_{4}$ and dried under reduced pressure at $80^{\circ} \mathrm{C}$ for $72 \mathrm{~h}$. In order to ensure a uniform dissolution of $\mathrm{LiClO}_{4}$ through film thickness, immersion was continued till the weight change of the dried film before and after immersion reached a constant level. Thus, the concentration of $\mathrm{LiClO}_{4}$ in the network film was controlled by changing the concentration of the $\mathrm{LiClO}_{4}$ solution and determined from the weight change of the films before and after immersion. The polymer electrolytes based on the network polymers are designated hereafter "crosslinked PEO- $\mathrm{LiClO}_{4}$ complexes."

In the case of linear PEO, the polymer electrolytes were prepared as follows. Preweighed amounts of PEO and $\mathrm{LiClO}_{4}$ were 
dissolved in distilled acetonitrile. The solvent was evaporated under dry nitrogen atmosphere at room temperature for $24 \mathrm{~h}$ and in vacuo at $40^{\circ} \mathrm{C}$ for another $72 \mathrm{~h}$, which allowed obtaining the "linear PEO- $\mathrm{LiClO}_{4}$ complex."

The concentration of $\mathrm{LiClO}_{4}$ in the PEO$\mathrm{LiClO}_{4}$ complexes was represented by the molar ratio of $\mathrm{LiClO}_{4}$ to the repeat unit of PEO ([ $\left.\mathrm{LiClO}_{4}\right] /\left[\mathrm{EO}\right.$ unit]). The PEO- $\mathrm{LiClO}_{4}$ complexes were handled in all cases under dry argon atmosphere. Before carrying out various measurements, the samples were kept in vacuo at room temperature for $24 \mathrm{~h}$.

\section{Method}

The PEO- $\mathrm{LiClO}_{4}$ complexes were cut into disks $(13 \mathrm{~mm}$ in dia.) for electrical measurements. The disk sample sandwiched between $\mathrm{Pt} / \mathrm{Pt}, \mathrm{Pt} / \mathrm{Li}, \mathrm{Li} / \mathrm{Li}$ electrodes (13 mm in dia.) was packed in a sealed cell under dry argon atmosphere. Alternating current measurements were made on the cell with a YokogawaHewlett-Packard 4192A impedance analyzer over a frequency range of 5 to $1.3 \times 10^{7} \mathrm{~Hz}$ at $0.5 \mathrm{~V}$ amplitude. Direct-current (dc) measurements were carried out by applying a constant voltage over the cell and measuring the current with an electrometer.

Differential scanning calorimetry (DSC) was carried out on a Rigaku Denki 8058 DSC apparatus at a heating rate of $20 \mathrm{~K} \mathrm{~min}^{-1}$. The glass transition zone was determined as the temperature range between two intersection points of the base lines with the extrapolated sloping portion of the DSC curves which resulted from a heat capacity change. Glass transition temperature $\left(T_{\mathrm{g}}\right)$ was defined as the mid-point of the heat capacity change. $\mathrm{X}$-Ray diffraction patterns were measured with a Rigaku Denki RAD-IIA X-ray diffractometer using a $\mathrm{Ni}$-filtered $\mathrm{Cu}-K_{\alpha}$ ray. Quantitative analysis of the amount of lithium was carried out with a Dai-ni Seiko SAS-727 atomic absorption/flame emission spectrophotometer.

\section{RESULTS AND DISCUSSION}

\section{Characterization of PEO- $\mathrm{LiClO}_{4}$ Complexes}

Figure 2 shows X-ray diffraction patterns of linear PEO, crosslinked PEO, and crosslinked PEO- $\mathrm{LiClO}_{4}$ complexes at room temperature. Apparent diffraction peaks were observed in the crosslinked PEO and crosslinked PEO$\mathrm{LiClO}_{4}$ complexes of $\left[\mathrm{LiClO}_{4}\right] /[\mathrm{EO}$ unit $]=0.01$ and 0.02 , whereas only halos were observed in the PEO- $\mathrm{LiClO}_{4}$ complexes of $\left[\mathrm{LiClO}_{4}\right] /$ [EO unit $]=0.05$ and 0.10 . This fact shows that the incorporation of $\mathrm{LiClO}_{4}$ inhibits the crystallization of the samples. Although the peak intensity of the crosslinked PEO and crosslinked $\mathrm{PEO}-\mathrm{LiClO}_{4}$ complexes of $\left[\mathrm{LiClO}_{4}\right] /[\mathrm{EO}$ unit] $=0.01$ and 0.02 was considerably lower than that of linear PEO, their peak positions were the same as those for linear PEO. The crystallites of these samples were those of pure PEO. Since no diffraction peaks of crystalline $\mathrm{LiClO}_{4}$ appeared in the crosslinked PEO$\mathrm{LiClO}_{4}$ complexes, the incorporated $\mathrm{LiClO}_{4}$ was dissolved in the amorphous region of the networks.

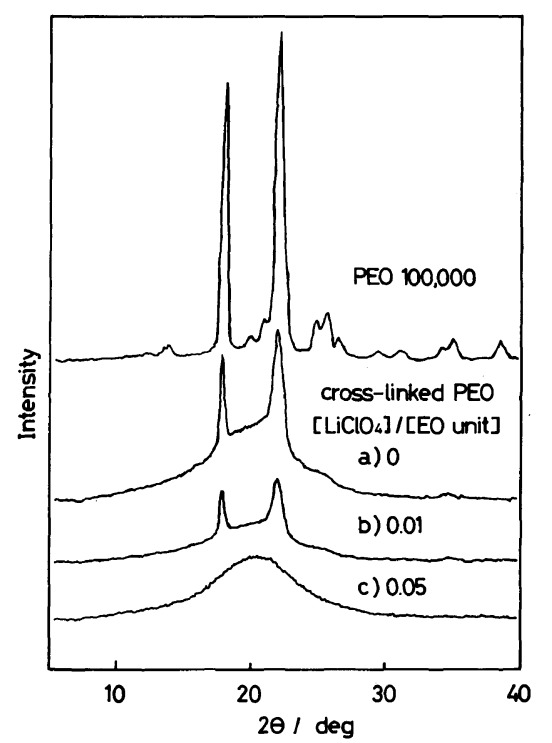

Figure 2. X-Ray diffraction patterns of linear PEO, crosslinked PEO, and crosslinked PEO- $\mathrm{LiClO}_{4}$ complexes. 


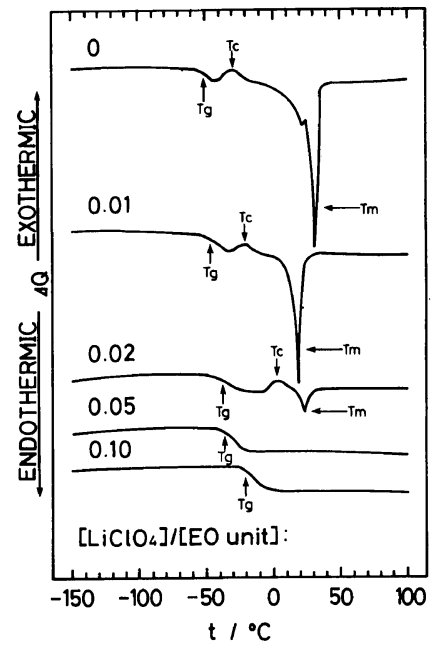

Figure 3. Profiles of DSC curves of crosslinked PEO and crosslinked PEO- $\mathrm{LiClO}_{4}$ complexes in the first run.

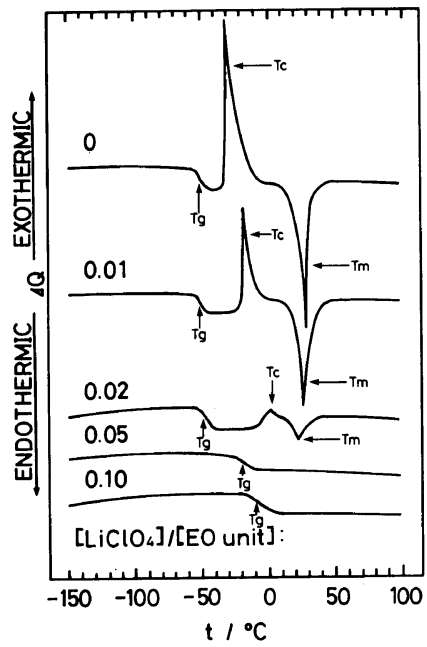

Figure 4. Profiles of DSC curves of crosslinked PEO and crosslinked PEO- $\mathrm{LiClO}_{4}$ complexes in the second run. Samples used were quenched from $+100^{\circ} \mathrm{C}$ to $-150^{\circ} \mathrm{C}$.

Figures 3 and 4 show the profiles of DSC curves of the crosslinked $\mathrm{PEO}-\mathrm{LiClO}_{4}$ complexes for the first and second runs, respectively. The profiles of DSC curves of the linear PEO and its complex are shown in Figure 5. The second runs were carried out after quenching the samples used in the first runs with liquid nitrogen from +100 or $200^{\circ} \mathrm{C}$ to $-150^{\circ} \mathrm{C}$ in the DSC apparatus, and here-

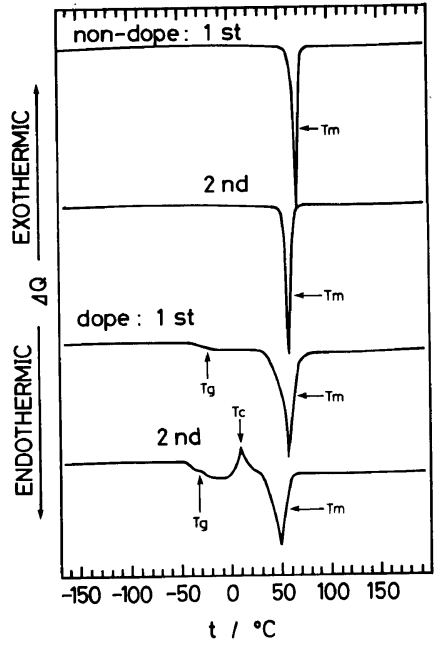

Figure 5. Profiles of DSC curves of linear PEO and linear $\mathrm{PEO}-\mathrm{LiClO}_{4}$ complex in the first and second runs. Samples used in the second run were quenched from $+200^{\circ} \mathrm{C}$ to $-150^{\circ} \mathrm{C}$.

after we represent the resulting samples as "quenched." The DSC results are summarized in Table II. The enthalpy of crystallization $\left(\Delta H_{\mathrm{c}}\right)$ and melting $\left(\Delta H_{\mathrm{m}}\right)$ were estimated by using phenylazobenzene as a standard substance. This enthalpy for the $\mathrm{PEO}-\mathrm{LiClO}_{4}$ complexes was represented as that per unit weight of either crosslinked PEO or linear PEO, since the crystallites of these complexes had the same structure as those of linear PEO. The degree of crystallinity was estimated from the ratio of the experimentally determined $\Delta H_{\mathrm{m}}$ to the value of $203 \mathrm{~J} \mathrm{~g}^{-1}$ reported in the literature ${ }^{22}$ for the enthalpy of melting of $100 \%$ crystalline PEO.

For the uncomplexed PEO network polymer, $T_{\mathrm{g}}$, crystallization temperature $\left(T_{\mathrm{c}}\right)$, and melting temperature $\left(T_{\mathrm{m}}\right)$ were detected from the DSC curve shown in Figure 3. The degree of crystallinity was $30 \%$. With the incorporation of $\mathrm{LiClO}_{4}$ in the network polymer, $T_{\mathrm{g}}$ of the samples increased and the degree of crystallinity decreased distinctly. The interaction of $\mathrm{Li}^{+}$ions with polar ether oxygen atoms suppressed the segmental motion of PEO, and this suppression also inhibited the crystal- 
Ionic Conductivity of PEO Electrolytes

Table II. DSC results of PEO and PEO- $\mathrm{LiClO}_{4}$ complexes

\begin{tabular}{|c|c|c|c|c|c|c|c|c|}
\hline \multirow{2}{*}{ Sample } & {$\left[\mathrm{LiClO}_{4}\right]$} & \multirow{2}{*}{ Run no. } & $T_{\mathrm{g}}$ (zone) & $T_{\mathrm{c}}$ & $\Delta H_{\mathrm{c}}$ & $T_{\mathrm{m}}$ & $\Delta H_{\mathrm{m}}$ & Crystallinity \\
\hline & [EO unit] & & ${ }^{\circ} \mathrm{C}$ & ${ }^{\circ} \mathrm{C}$ & $\mathrm{Jg}^{-1}$ & ${ }^{\circ} \mathrm{C}$ & $\mathrm{Jg}^{-1}$ & $\%$ \\
\hline \multirow{6}{*}{$\begin{array}{l}\text { Crosslinked } \\
\text { PEO }\end{array}$} & 0 & 1 & $-51(-58$ to -44$)$ & -31 & 5.1 & 32 & 60.5 & 30 \\
\hline & & 2 & $-54(-59$ to -49$)$ & -31 & 39.6 & 29 & 48.6 & \\
\hline & 0.01 & $\begin{array}{l}1 \\
2\end{array}$ & $\begin{array}{l}-43(-51 \text { to }-31) \\
-49(-55 \text { to }-45)\end{array}$ & $\begin{array}{l}-19 \\
-26\end{array}$ & $\begin{array}{r}2.2 \\
31.6\end{array}$ & $\begin{array}{l}19 \\
27\end{array}$ & $\begin{array}{l}50.9 \\
44.9\end{array}$ & 25 \\
\hline & 0.02 & $\begin{array}{l}1 \\
2\end{array}$ & $\begin{array}{l}-43(-48 \text { to }-38) \\
-44(-48 \text { to }-39)\end{array}$ & $\begin{array}{l}2 \\
3\end{array}$ & $\begin{array}{l}5.7 \\
4.4\end{array}$ & $\begin{array}{l}23 \\
23\end{array}$ & $\begin{array}{l}6.1 \\
4.9\end{array}$ & 3 \\
\hline & 0.05 & $\begin{array}{l}1 \\
2\end{array}$ & $\begin{array}{l}-30(-35 \text { to }-24) \\
-30(-36 \text { to }-24)\end{array}$ & & & & & 0 \\
\hline & 0.10 & $\begin{array}{l}1 \\
2\end{array}$ & $\begin{array}{l}-15(-27 \text { to }-4) \\
-16(-25 \text { to }-7)\end{array}$ & & & & & 0 \\
\hline \multirow[t]{2}{*}{ Linear PEO } & 0 & $\begin{array}{l}1 \\
2\end{array}$ & & & & $\begin{array}{l}67 \\
59\end{array}$ & $\begin{array}{l}155 \\
124\end{array}$ & 76 \\
\hline & 0.05 & $\begin{array}{l}1 \\
2\end{array}$ & $\begin{array}{l}-22(-36 \text { to }-11) \\
-29(-39 \text { to }-16)\end{array}$ & 11 & 18.1 & $\begin{array}{l}56 \\
48\end{array}$ & $\begin{array}{l}82.3 \\
42.4\end{array}$ & 41 \\
\hline
\end{tabular}

lization of PEO segments. The crosslinked $\mathrm{PEO}-\mathrm{LiClO}_{4}$ complexes of $\left[\mathrm{LiClO}_{4}\right] /[\mathrm{EO}$ unit] $=0.05$ and 0.10 thus became completely amorphous.

In the quenched samples shown in Figure 4 , the crystallization appeared clear. The values of $\Delta H_{\mathrm{c}}$ were comparable to those of $\Delta H_{\mathrm{m}}$, which showed that crystallization could not occur in the quenching process. The complexes of $\left[\mathrm{LiClO}_{4}\right] /[\mathrm{EO}$ unit $]=0.05$ and 0.10 were amorphous, independent of their thermal history.

Comparison of the DSC results between the crosslinked PEO- $\mathrm{LiClO}_{4}$ complexes and linear PEO- $\mathrm{LiClO}_{4}$ complex made the following facts clear. The degree of crystallinity of the linear PEO was high, and $T_{\mathrm{g}}$ could not be detected. The rate of the crystallization was also high, since the crystallization peak could not be detected in the quenched sample and its $\Delta H_{\mathrm{m}}$ was comparable to that of the annealed sample. The degree of crystallinity of the linear $\mathrm{PEO}-\mathrm{LiClO}_{4}$ complex was $40 \%$, whereas that of the crosslinked PEO- $\mathrm{LiClO}_{4}$ complex was completely amorphous at the same $\mathrm{LiClO}_{4}$ concentration. Thus, the network structure decreased the degree of crystallinity and lowered the rate of the crystallization.

\section{$\mathrm{Li}^{+}$Ion Conduction in Crosslinked PEO- $\mathrm{LiClO}_{4}$ Complexes}

There have been many reports on cation transport in PEO-salt complexes. However, the cationic transport number is still a matter of controversy. ${ }^{7,23-29}$ Here we demonstrate $\mathrm{Li}^{+}$ion conduction in the crosslinked PEO$\mathrm{LiClO}_{4}$ complexes by using the dc methods. Figure 6 shows time dependence of current during dc-electrolysis at $1.0 \mathrm{~V}$. The current through the platinum electrode cell decreased rapidly and after $60 \mathrm{~min}$ reached the current level, which was smaller than that of the lithium electrode cell by two orders of magnitude. The current decrease in the lithium electrode cell was small, and the ratio of the current at $60 \mathrm{~min}$ to the initial value was 0.31 . This shows that $\mathrm{Li}^{+}$ions are charge carriers in this complex. Figure 7 shows the results of the electrolytic experiment at 3.0 $\mathrm{V}$ for the cell configuration shown in the 


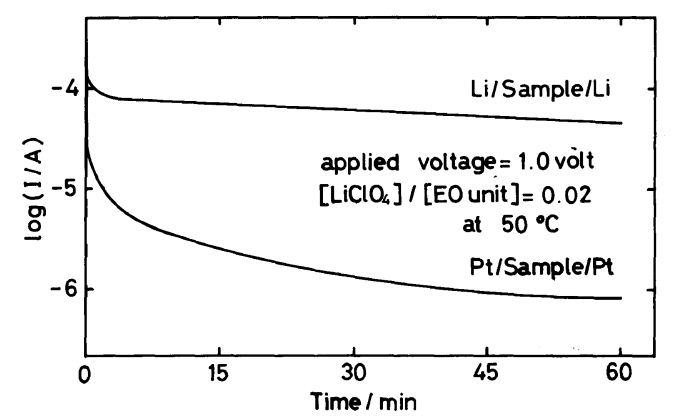

Figure 6. Time dependence of current under $1.0 \mathrm{~V}$ application for crosslinked $\mathrm{PEO}-\mathrm{LiClO}_{4}$ complex $\left(\left[\mathrm{LiClO}_{4}\right] /[\mathrm{EO}\right.$ unit $\left.]=0.02\right)$ at $50^{\circ} \mathrm{C}$.

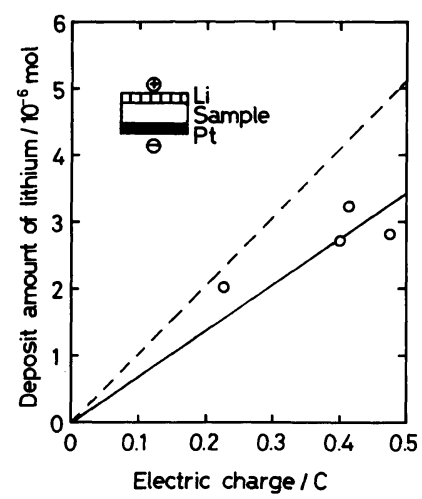

Figure 7. Relation between deposited amount of lithium onto platinum cathode and electric charge through the cell for crosslinked $\mathrm{PEO}-\mathrm{LiClO}_{4}$ complex $\left(\left[\mathrm{LiClO}_{4}\right] /[\mathrm{EO}\right.$ unit $\left.]=0.02\right)$ at $50^{\circ} \mathrm{C}$.

figure. After electrolyzed for a given period, the platinum cathode was peeled-off and immersed in a $\mathrm{HCl}$ aqueous solution. The amount of the deposited lithium was measured by using these solutions. The amount of the deposited lithium tended to increase with increasing the electric charge through the cell. The dashed line in the figure shows the calculated amount of lithium according to the Faraday's law. Since the polarization was encountered in the experiment, the coulometric efficiency of the electrolysis was expected to vary with time. However, the average efficiency was 0.67 . The reason for the lower efficiency than unity might be due to the polarization of $\mathrm{Li}^{+}$and $\mathrm{ClO}_{4}^{-}$ions and the decom-

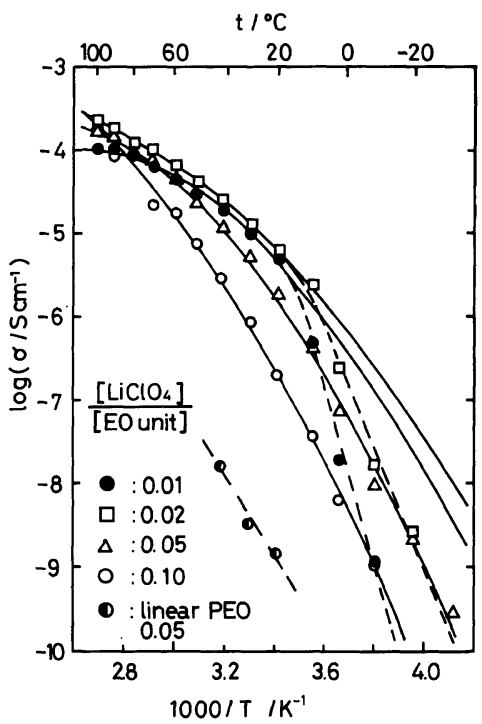

Figure 8. Arrhenius plots of ionic conductivity for crosslinked PEO- $\mathrm{LiClO}_{4}$ complexes and linear PEO$\mathrm{LiClO}_{4}$ complex. Solid lines in the figure are calculated curves using WLF-type equation and parameters shown in Table III.

position reaction of $\mathrm{ClO}_{4}^{-}$ions at the interface.

From these results, it is shown that $\mathrm{Li}^{+}$ions are charge carriers in the crosslinked PEO$\mathrm{LiClO}_{4}$ complex. However, the transport of $\mathrm{ClO}_{4}^{-}$ions cannot be neglected.

Temperature Dependence of Ionic Conductivity

In Figure 8 are shown Arrhenius plots of the ionic conductivity for the crosslinked PEO$\mathrm{LiClO}_{4}$ complexes. The ionic conductivity was calculated from the bulk resistance found in the complex impedance diagrams of the platinum electrode cells. The conductivity data of the linear PEO- $\mathrm{LiClO}_{4}$ complex are also shown in the figure. The conductivity for the crosslinked complexes of $\left[\mathrm{LiClO}_{4}\right] /[\mathrm{EO}$ unit $]$ $=0.01$ and 0.02 decreased suddenly at about 20 and $10^{\circ} \mathrm{C}$, respectively. These decreases corresponded to the crystallization of the PEO segments, which was confirmed by the X-ray and DSC results. The Arrhenius plots of the conductivity for the crosslinked complexes of $\left[\mathrm{LiClO}_{4}\right] /[\mathrm{EO}$ unit $]=0.05$ and 0.10 showed 
Table III. WLF parameters for crosslinked PEO- $\mathrm{LiClO}_{4}$ complexes

\begin{tabular}{|c|c|c|c|c|}
\hline$\left[\mathrm{LiClO}_{4}\right]$ & $T_{\mathrm{g}}$ & & $C_{2}$ & $\sigma\left(T_{\mathrm{g}}\right)$ \\
\hline [EO unit] & ${ }^{\circ} \mathrm{C}$ & & ${ }^{\circ} \mathrm{C}$ & $\mathrm{Scm}^{-1}$ \\
\hline 0.01 & -43 & 9.58 & 31.6 & $2.1 \times 10^{-12}$ \\
\hline 0.02 & -43 & 10.6 & 29.9 & $4.0 \times 10^{-13}$ \\
\hline 0.05 & -30 & 10.2 & 36.4 & $2.4 \times 10^{-12}$ \\
\hline 0.10 & -15 & 9.91 & 65.6 & $8.2 \times 10^{-11}$ \\
\hline
\end{tabular}

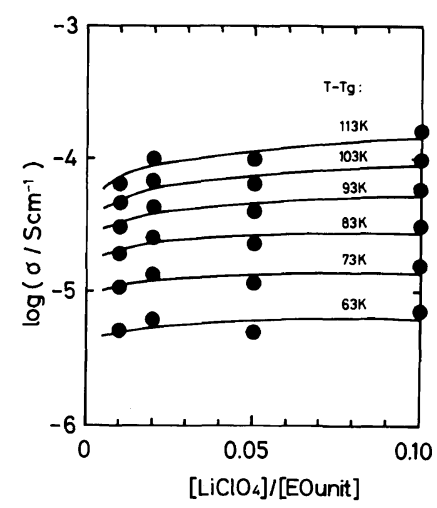

Figure 9. Logarithm of conductivity $v s$. $\left[\mathrm{LiClO}_{4}\right] /[\mathrm{EO}$ unit] at various reduced temperature $\left(T-T_{\mathrm{g}}\right)$ for crosslinked $\mathrm{PEO}-\mathrm{LiClO}_{4}$ complexes.

positively curved profiles in the whole temperature range. For the crosslinked complexes of $\left[\mathrm{LiClO}_{4}\right] /[\mathrm{EO}$ unit $]=0.01$ and 0.02 , the Arrhenius plots also deviated positively from the straight line above 20 and $10^{\circ} \mathrm{C}$, respectively. Since these curved profiles appeared in the temperature range where the samples were in rubbery and amorphous state, the temperature dependence of the ionic conductivity was fitted to the following WilliamsLandel-Ferry (WLF) type equation. ${ }^{30}$

$$
\log \frac{\sigma(T)}{\sigma\left(T_{\mathrm{g}}\right)}=\frac{C_{1}\left(T-T_{\mathrm{g}}\right)}{C_{2}+\left(T-T_{\mathrm{g}}\right)}
$$

The parameters obtained are summarized in Table III. The calculated temperature dependence of the ionic conductivity from the equation and parameters in Table III is shown in Figure 8 by solid lines. The curved profile was reproduced very well by this calcu- lation. Since the WLF type equation has been derived from the free volume theory, ${ }^{31}$ the transport of ionic carriers may obey the free volume mechanism. Figure 9 shows the $\log \sigma$ vs. $\left[\mathrm{LiClO}_{4}\right] /[\mathrm{EO}$ unit] plots at various reduced temperatures $\left(T-T_{\mathrm{g}}\right)$. The free volume theory generally gives the iso-free-volume state at a constant $T-T_{\mathrm{g}}$ in a similar media. Thus, the ionic mobility might be considered to be nearly the same at a constant $T-T_{\mathrm{g}}$. If the incorporated $\mathrm{LiClO}_{4}$ dissociates completely in the crosslinked PEO, the conductivity at a constant $T-T_{\mathrm{g}}$ increases in proportion to the $\mathrm{LiClO}_{4}$ concentration. However, the increase in the conductivity in Figure 9 was smaller than that expected by the complete dissociation of $\mathrm{LiClO}_{4}$. Thus, it is suggested that a part of the incorporated $\mathrm{LiClO}_{4}$ dissociates and that the dissociated ions $\left(\mathrm{Li}^{+}\right.$and $\left.\mathrm{ClO}_{4}^{-}\right)$ and/or aggregated ions (e.g., $\mathrm{Li}^{+} \mathrm{ClO}_{4}^{-} \mathrm{Li}^{+}$ and $\mathrm{ClO}_{4}^{-} \mathrm{Li}^{+} \mathrm{ClO}_{4}^{-}$) are mobile in the crosslinked PEO.

Figure 8 also shows that the conductivity at a constant temperature takes a maximum at $\left[\mathrm{LiClO}_{4}\right] /[\mathrm{EO}$ unit $]=0.02$ in the amorphous state. The WLF type equation does not take into account the number of carrier ions. However, it is plausible that the number of carrier ions increases with increasing $\mathrm{LiClO}_{4}$ concentration. The increase in $\mathrm{LiClO}_{4}$ concentration brings about, at the same time, an increase in $T_{\mathrm{g}}$ of the crosslinked PEO$\mathrm{LiClO}_{4}$ complexes, as shown in Table III. Since the WLF type equation holds for the temperature dependence of ionic mobility, in principle, and the main influencing term in the equation is $T-T_{\mathrm{g}}$, the ionic mobility at a constant temperature might decrease with increasing $\mathrm{LiClO}_{4}$ concentration. The maximum conductivity may be caused by these two opposite effects ${ }^{9,13,32,33}$ on the ionic conductivity as a function of $\mathrm{LiClO}_{4}$ concentration.

\section{Effects of Crystallinity on Ionic Conductivity}

The ionic conductivity of the crosslinked 
PEO- $\mathrm{LiClO}_{4}$ complexes was considerably higher than that of the linear PEO- $\mathrm{LiClO}_{4}$ complex, as seen in Figure 8. The conductivity of the crosslinked PEO- $\mathrm{LiClO}_{4}$ complex of $\left[\mathrm{LiClO}_{4}\right] /[\mathrm{EO}$ unit $]=0.02$ reached the order of $10^{-5} \mathrm{~S} \mathrm{~cm}^{-1}$ at $30^{\circ} \mathrm{C}$, which belongs to a highly conductive class in the polymer electrolytes ever reported..$^{8,32-34}$ The difference in the conductivity for both complexes seems to be due to the high crystallinity of the linear PEO- $\mathrm{LiClO}_{4}$ complex. The incorporated $\mathrm{LiClO}_{4}$ in the linear PEO was dissolved in the amorphous region. The crystallization of PEO segments caused exclusion of the incorporated $\mathrm{LiClO}_{4}$ from the crystallites. Thus, the $\mathrm{LiClO}_{4}$ concentration in the amorphous region should be higher than that of the apparent value of 0.05 . The higher concentration in the amorphous region may cause both increases in the number of carrier ions and in $T_{\mathrm{g}}$. The increase in $T_{\mathrm{g}}$ by crystallization was confirmed by the DSC results, on comparing the $T_{\mathrm{g}} \mathrm{s}$ of the linear and crosslinked PEO$\mathrm{LiClO}_{4}$ complexes of $\left[\mathrm{LiClO}_{4}\right] /[\mathrm{EO}$ unit $]=0.05$ in the first runs. It was also confirmed that the $T_{\mathrm{g}} \mathrm{s}$ were similar in the second runs, where the linear $\mathrm{PEO}-\mathrm{LiClO}_{4}$ complex was made almost amorphous by quenching. The decrease in carrier mobility due to increase in $T_{\mathrm{g}}$ seems to predominate over the increase in the number of carrier ions. Thus, the conductivity of the linear PEO- $\mathrm{LiClO}_{4}$ complex was lower than that of the crosslinked $\mathrm{PEO}-\mathrm{LiClO}_{4}$ complex. Indeed, this condensation effect of the $\mathrm{LiClO}_{4}$ concentration in the amorphous region is one reason for the lower conductivity of the linear PEO- $\mathrm{LiClO}_{4}$ complex, but we could not explain the lower conductivity in terms of condensation effects alone. The $\mathrm{LiClO}_{4}$ concentration in the amorphous region, estimated by using the degree of crystallinity, was lower than $\left[\mathrm{LiClO}_{4}\right] /[\mathrm{EO}$ unit] $=0.10$. The $T_{\mathrm{g}}$ value also agreed with this estimation. However, its conductivity was far lower than that of the crosslinked PEO$\mathrm{LiClO}_{4}$ complex of $\left[\mathrm{LiClO}_{4}\right] /[\mathrm{EO}$ unit $]=0.10$.
Thus, the exsistence of the crystallites affects considerably ionic conductivity. The interface between the crystallites and amorphous region may function as a deep trap for the ionic migration. The crystallites also sterically hinder ionic migration. These effects in addition to the condensation effects may be responsible for the lower ionic conductivity for the linear PEO- $\mathrm{LiClO}_{4}$ complex.

The sudden decrease in conductivity for the crosslinked complexes of $\left[\mathrm{LiClO}_{4}\right] /[\mathrm{EO}$ unit] $=0.01$ and 0.02 may also be explained by these effects.

It can be concluded that the crosslinked structure of PEO causes a considerable decrease in the degree of crystallinity. This fact contributes to the high ionic conductivity. As a result, we could obtain a $\mathrm{Li}^{+}$-conductive polymer electrolyte having the conductivity of $10^{-5} \mathrm{~S} \mathrm{~cm}^{-1}$ at $30^{\circ} \mathrm{C}$.

\section{REFERENCES}

1. (a) R. Iwamoto, Y. Saito, H. Ushihara, and H. Tadokoro, J. Polym. Sci., A-2, 6, 1509 (1968); (b) M. Yokoyama, H. Ishihara, R. Iwamoto, and $\mathbf{H}$. Tadokoro, Macromolecules, 2, 184 (1969).

2. (a) J. Parrod and A. Kohler, J. Polym. Sci., 48, 457 (1960); (b) H. Tadokoro, T. Yoshihara, Y. Chatani, and S. Murahashi, J. Polym. Sci., B, 2, 363 (1964).

3. (a) D. E. Fenton, J. M. Parker, and P. V. Wright, Polymer, 14, 589 (1973); (b) P. V. Wright, Br. Polym. J., 7, 319 (1975); (c) P. V. Wright, J. Polym. Sci., Polym. Phys. Ed., 14, 955 (1976).

4. M. B. Armand, J. M. Chabagno, and M. J. Duclot, "Fast Ion Transport in Solid," P. Vashishta, J. N. Mundy, and D. K. Shenoy, Ed., North Holland Publishing Co., Amsterdam, 1979, p 131.

5. (a) B. L. Papke, M. A. Ratner, and D. F. Shriver, $J$. Phys. Chem. Solids, 42, 493 (1981); (b) R. Dupon, B. L. Papke, M. A. Ratner, D. H. Whitmore, and D. F. Shriver, J. Electrochem. Soc., 129, 1694 (1982).

6. F. L. Tanzella, W. Bailey, D. Frydrych, G. C. Farrington, and H. S. Story, Solid State Ionics, 5, 681 (1981).

7. (a) J. E. Weston and B. C. H. Steele, Solid State Ionics, 2, 347 (1981); (b) J. E. Weston and B. C. H. Steele, Solid State Ionics, 7, 75 (1981); (c) J. E. Weston and B. C. H. Steele, Solid State Ionics, 7, 81 (1982).

8. (a) J. M. Parker, P. V. Wright, and C. C. Lee, 
Polymer, 22, 1305 (1981); (b) C. C. Lee and P. V. Wright, Polymer, 23, 681 (1982); (c) D. R. Payne and P. V. Wright, Polymer, 23, 712 (1982).

9. (a) H. Cheradame, J. L. Souquet, and J. M. Latour, Mater. Res. Bull., 15, 1173 (1980); (b) A. Killis, J. F. LeNest, H. Cheradame, and A. Gandini, Makromol. Chem., 183, 2835 (1982); (c) H. Cheradame, "IUPAC Macromolecules," H. Benoit and P. Rempp, Ed., Pergamon Press, Oxford and New York, 1982, p 251; (d) A. Killis, J. F. LeNest, A. Gandini, and H. Cheradame, Macromolecules, 17, 63 (1984).

10. C. K. Chiang, G. T. Davis, C. A. Harding, and J. Aarons, Sotid State Ionics, 9 \& 10, 1121 (1983).

11. M. Minier, C. Berthier, and W. Gorecki, J. Physique, 45, 739 (1984).

12. J. R. Maccalum, M. J. Smith, and C. A. Vincent, Solid State Ionics, 11, 307 (1984).

13. (a) M. Watanabe, K. Nagaoka, M. Kanba, and I Shinohara, Polym. J., 14, 877 (1982); (b) M. Watanabe, J. Ikeda, and I. Shinohara, Polym. J., 15, 65 (1983); (c) M. Watanabe, J. Ikeda, and I. Shinohara, ibid., 15, 175 (1983).

14. M. Watanabe, K. Sanui, N. Ogata, T. Kobayashi, and Z. Ohtaki, J. Appl. Phys., 57, 123 (1985).

15. (a) M. Watanabe, K. Sanui, N. Ogata, F. Inoue, T. Kobayashi, and Z. Ohtaki, Polym. J., 16, 711 (1984); (b) M. Watanabe, K. Sanui, N. Ogata, F. Inoue, T. Kobayashi, and Z. Ohtaki, Polym. J., 17, 549 (1985).

16. M. Watanabe, S. Oohashi, K. Sanui, N. Ogata, T. Kobayashi, and Z. Ohtaki, Macromolecules, 18, 1945 (1985).

17. M. Watanabe, M. Togo, K. Sanui, N. Ogata, T. Kobayashi, and Z. Ohtaki, Macromolecules, 17, 2908 (1984).

18. M. Watanabe, M. Rikukawa, K. Sanui, N. Ogata, H. Kato, T. Kobayashi, and Z. Ohtaki, Macro- molecules, 17, 2902 (1984).

19. M. Watanabe, M. Rikukawa, K. Sanui, and N. Ogata, Macromolecules, 19, 188 (1986).

20. K. Nagaoka, H. Naruse, I. Shinohara, and M. Watanabe, J. Polym. Sci., Polym. Lett. Ed., 22, 659 (1984).

21. P. Ferloni, G. Chiodelli, A. Magistris, and M. Sanesi, Solid States Ionics, 18 \& 19, 265 (1986).

22. B. Wunderlich, "Macromolecular Physics," Vol. 3, Academic Press, New York, 1980, p 67.

23. P. R. Sorensen and T. Jacobsen, Electrochim. Acta, 27, 1671 (1982).

24. M. Leveque, J. F. LeNest, A. Gandini, and H. Cheradame, Makromol. Chem., Rapid Commun., 4, 497 (1983).

25. M. Armand, Solid State Ionics, 9 \& 10, 745 (1983).

26. 26. A. V. Chadwick, J. H. Strange, and M. R. Worboys, Solid State Ionics, 9 \& 10, 1155 (1983).

27. A. Bouridah, F. Dalard, D. Deroo, and M. B. Armand, Solid State Ionics, 18 \& 19, 287 (1986).

28. W. Gorecki, R. Andeani, C. Berthier, and M. Armand, M. Mali, J. Roos, and D. Brinkmann, Solid State Ionics, 18 \& 19, 295 (1986).

29. S. Bhattacharja, S. W. Smoot, and D. H. Whitmore, Solid State Ionics, 18 \& 19, 306 (1986).

30. M. L. Williams, R. F. Landel, and J. D. Ferry, J. Am. Chem. Soc., 77, 3701 (1955).,

31. M. H. Cohen and D. Turnbull, J. Chem. Phys., 31, 1164 (1959).

32. N. Kobayashi, M. Uchiyama, K. Shigehara, and E Tsuchida, J. Phys. Chem., 89, 987 (1985).

33. P. M. Blonsky, D. F. Shriver, P. Austin, and H. R Allcock, J. Am. Chem. Soc., 106, 987 (1985).

34. D. J. Bannister, G. R. Davies, I. M. Ward, and J. E. McIntyre, Polymer, 25, 1600 (1984). 